1 Wick G: 'Anti-aging' medicine: does it exist? A critical discussion of 'anti-aging health products'. Exp Gerontol 2002;37:1137-1140.

2 Ralli EP, Friedman GJ, Rubin SH: The mechanism of the excretion of vitamin $\mathrm{C}$ by the human kidney. J Clin Invest 1938;17:765770 .

3 Baker EM, Saari JC, Tolbert BM: Ascorbic acid metabolism in man. Am J Clin Nutr 1966;19:371-378.
4 Balcke P, Schmidt P, Zazgornik J, Kopsa H, Haubenstock A: Ascorbic acid aggravates secondary hyperoxalemia in patients on chronic hemodialysis. Ann Intern Med 1984; 101:344-345.

5 Ono K: Secondary hyperoxalemia caused by vitamin $\mathrm{C}$ supplementation in regular hemodialysis patients. Clin Nephrol 1986;26: 239-243.

6 Pru C, Eaton J, Kjellstrand C: Vitamin C intoxication and hyperoxalemia in chronic hemodialysis patients. Nephron 1985;39:112116.

7 Mashour S, Turner JF Jr, Merrell R: Acute renal failure, oxalosis, and vitamin C supplementation: a case report and review of the literature. Chest 2000;118:561-563.
8 Alkhunaizi AM, Chan L: Secondary oxalosis: a cause of delayed recovery of renal function in the setting of acute renal failure. J Am Soc Nephrol 1996;7:2320-2326.

9 Wong K, Thomson C, Bailey RR, McDiarmid S, Gardner J: Acute oxalate nephropathy after a massive intravenous dose of vitamin C. Aust NZ J Med 1994;24:410-411.

10 Nasr SH, Kashtanova Y, Levchuk V, Markowitz GS: Secondary oxalosis due to excess vitamin C intake. Kidney Int 2006;70:1672.

\title{
Announcement
}

\section{Ninth International Symposium on Neurobiology and Neuroendocrinology of Aging}

Bregenz, July 20-25, 2008

The objective of these symposia is to bring together scientists who have made recent major advances in the study of aging, ranging from neuroendocrinology, neurobiology, genetics, and molecular mechanisms to practical issues of treatment and care of the elderly and patients with age-related cognitive decline. Our goals are to bring together speakers who normally would not meet at a conference devoted solely to Alzheimer's disease, molecular biology of aging, clinical geriatrics, or other commonly covered topics. We hope to maintain a similarly wide representation at the 2008 gathering.

The format of the meeting is four and a half days of brief lectures with ample time for discussion, and afternoons left open for recreation and informal interactions. This creates an atmosphere conducive to in-depth analysis of research results and their implications. The site of the meeting is in a renovated complex of beautiful old buildings of the Collegium Bernardi, a boarding school operated by Kloster Mehrerau, within walking distance of the shore of the magnificent Lake Constance, Bregenz City Park, and a nature preserve.
For a current list of speakers and other information, please view the following site:

http://www.neurobiology-and-neuroendocrinology-of-aging.org

For more information, please contact:

Dr. Andrzej Bartke

Southern Illinois University School of Medicine

PO Box 19628, 801 North Rutledge, Room 4389

Springfield, IL 62794-9628 (USA)

E-Mail abartke@siumed.edu

or

Dr. Richard E. Falvo

Department of Cell and Molecular Physiology

Medical Biomolecular Research Building, 111 Mason Farm Road

School of Medicine, University of North Carolina at Chapel Hill

Chapel Hill, NC 27599-7545 (USA)

E-Mail rfalvo@med.unc.edu 